\title{
De SARS-CoV-2-antigeentest is niet accuraat genoeg
}

Febe Smits, Bart Torensma, Rolf Groenwold, Maurine Leversteijn-Van Hall, Nathalie van Burgel, Robert Jansen, et al.

\begin{abstract}
Met een antigeensneltest kan een besmetting met SARS-CoV-2 binnen enkele minuten worden aangetoond. Wij onderzochten de validiteit van zo'n antigeentest in de eerstelijns spoedzorg bij patiënten met matig-ernstige corona-achtige klachten. De onderzochte antigeentest bleek een sensitiviteit te hebben van $65,7 \%$ en een negatief voorspellende waarde van $95-98 \%$. Het is daarom aan te raden om een negatieve sneltestuitslag bij patiënten die klachten hebben altijd te bevestigen met een PCR-test.
\end{abstract}

Om blootstelling aan SARS-CoV-2 te voorkomen triëren huisartsenpraktijken alle patiënten die bellen voor een afspraak op coronagerelateerde klachten. Als de patiënt klachten heeft die passen bij COVID-19 (hoesten, koorts, kortademigheid, keelpijn, verlies van reuk en smaak) kan de huisarts besluiten om de patiënt eerst naar een GGD-teststraat te verwijzen en pas na een negatieve PCR-testuitslag op de praktijk uit te nodigen.

Met de toenemende beschikbaarheid van antigeensneltests (hierna kortweg 'antigeentests' te noemen), zal het steeds vaker voorkomen dat patiënten bij het maken van de afspraak melden dat ze over een negatieve sneltestuitslag beschikken. Huisartsen zouden in principe zelfs een antigeentest voor de deur kunnen afnemen.

Er zijn tot nu toe enkele validatieonderzoeken uitgevoerd naar de nauwkeurigheid van antigeentests en er loopt nog een groot aantal onderzoeken in verschillende populaties (kwetsbare groepen, zorgmedewerkers, asymptomatisch en symptomatisch). ${ }^{1}$ De resultaten van het eerste Nederlandse validatieonderzoek met de Panbio ${ }^{\mathrm{Tm}}$ antigeentest van Abbott waren dermate positief dat de vraag ontstond of zulke antigeentests zouden kunnen worden ingezet in de eerstelijnszorg. ${ }^{2,3}$ Ons onderzoek had tot doel de negatief voorspellende waarde van deze antigeentest te bepalen. We richtten ons op patiënten met symptomen passend bij COVID-19 die zich bij de huisartsenpost meldden met een klacht die niet kon wachten op een reguliere coronatest. Vooraf stelden we als criteria voor implementatie van de antigeentest een sensitiviteit van $\geq 95 \%$ en een specificiteit van $\geq 99 \%$.

\section{METHODE}

Patiënten op coronahuisartsenpost

Wij deden een onderzoek naar de diagnostische waarde van de COVID-19 antigeentest bij de bezoekers van de coronahuisartsenposten in Leiderdorp en Den Haag. Dit onderzoek was goedgekeurd door de medisch-ethische commissie van het LUMC. Patienten gaven informed consent.

Naar deze coronaposten werden patiënten verwezen met klachten passend bij COVID-19 en met daarnaast een zodanige spoedindicatie (U3 bij triage) dat de uitslag van de reguliere PCR-test niet kon worden afgewacht. De inclusie vond plaats tussen 16 november 2020 en 18 januari 2021. In de regionale GGD-teststraten was het percentage positieve PCR-tests in deze periode $9-15 \%{ }^{4,5}$ Exclusiecriteria waren leeftijd $<18$ jaar, een recente $(<2$ weken) positieve PCR-testuitslag voor SARS-CoV-2 of onvoldoende beheersing van de Nederlandse taal.

\section{Antigeentest}

De deelnemers ondergingen de standaard PCR-test en daarnaast de Panbio ${ }^{\text {Tm }}$ antigeentest. ${ }^{6}$ Die laatste werd uitgevoerd door getrainde doktersassistenten met een nasofaryngeale swab volgens het protocol van de fabrikant. De uitslag van de antigeentest, die na 15 minuten kon worden afgelezen, werd medegedeeld aan de deelnemers, met het nadrukkelijke advies om ook bij een negatieve uitslag van de antigeentest die van de PCR-test thuis in quarantaine af te wachten. Daarnaast vulden de deelnemers een vragenlijst in over de duur van de symptomen, de medische voorgeschiedenis en het medicatiegebruik. 


\section{PCR-test}

De nasofaryngeale swabs werden verwerkt in de microbiologische laboratoria van het Alrijne Ziekenhuis te Leiderdorp en het Haga Ziekenhuis te Den Haag. De real-time polymerasekettingreactie (RT-PCR) werd uitgevoerd volgens de standaardprocedure met RNA-amplificatie in 45 cycli, waarbij de uitslag als positief gold zodra 1 van de 2 of 3 SARS-CoV-2-genen in het monster kon worden aangetoond.

Een positieve PCR-uitslag wordt uitgedrukt als cycle threshold (CT): het aantal cycli (maximaal 45) dat nodig was om de hoeveelheid genetisch materiaal voldoende te vermenigvuldigen om gedetecteerd te kunnen worden. Naast de reguliere PCR-analyse werd een tweede analyse gedaan met $\mathrm{CT} \geq 32$ als drempelwaarde voor een negatief testresultaat. In recente onderzoeken naar de relatie tussen PCR-uitslagen en besmettelijkheid is namelijk gebleken dat in samples met CT-waarden $\geq 32$ geen virusreplicatie meer optreedt zodat de persoon in kwestie als 'niet-besmettelijk' kan worden beschouwd..$^{7-9}$

\section{Analyse}

We berekenden de sensitiviteit, specificiteit en negatief voorspellende waarde van de antigeentest door de uitslagen te vergelijken met die van de PCR-test als gouden standaard.

\section{RESULTATEN}

Op de corona-huisartsenposten werden 534 patiënten geïncludeerd. Hun mediane leeftijd was 50 jaar (interkwartielafstand (IQR) 33-65) en 64,2\% was vrouw. De mediane duur van de klachten was 5 dagen (IQR 2-9). Bij 70 deelnemers (13\%) was de PCR-uitslag positief voor SARS-CoV-2. De [online tabel] laat de resultaten van de antigeentest zien ten opzichte van die van de PCR-test bij 2 drempelwaarden.

Bij de standaard PCR-drempelwaarde CT 45 had de antigeentest een sensitiviteit van 65,7\% (95\%-BI 54,6 tot 76,8) en een specificiteit van 100,0\% (95\%-BI 99,2 tot 100,0). De antigeentest miste de diagnose COVID-19 dus bij 34,3\% van de patiënten die een positief PCR-testresultaat hadden. De negatief voorspellende waarde was 95,1\% (95\%-BI 93,1\%, 97,0\%). Bij de 24 patiënten met een fout-negatieve antigeentest was de mediane CT-waarde 33,3 (IQR 29,9-35,6) en de mediane klachtenduur 9 dagen (IQR 5-11); 11 van hen hadden een klachtenduur van $\leq 7$ dagen.

Als de drempelwaarde voor een negatief PCR-testresultaat zou worden verlaagd naar $\mathrm{CT} \geq 32$, zou de sensitiviteit van de antigeentest $80,7 \%$ zijn (95\%-BI 70,5 tot 90,9), de specificiteit $100 \%$ en de negatief voorspellende waarde $97,7 \%$ (95\%-BI $96,4$ tot 99,1$)$.

Als we alleen patiënten met een klachtenduur $\leq 7$ dagen in de analyse zouden betrekken, zou de antigeentest een sensitiviteit hebben van 70,7\% (95\%-BI 59,0 tot $82,4 \%$ ).

\section{BESCHOUWING}

De PCR-test is de gevoeligste methode om een SARS-CoV2-besmetting aan te tonen. Nadeel is dat het gemiddeld 7-12

\section{WAT IS BEKEND?}

- De polymerasekettingreactie [PCR] is de gouden standaard voor het aantonen van een besmetting met SARS-CoV-2, maar de testuitslag is pas beschikbaar na gemiddeld 7-12 uur.

- De Wereldgezondheidsorganisatie [WHO] en het Rijksinstituut voor Volksgezondheid en Milieu [RIVM] hebben inmiddels enkele antigeentests goedgekeurd waarmee een besmetting met SARS-CoV-2 binnen enkele minuten kan worden aangetoond.

- Om de antigeentest in de eerstelijnszorg te kunnen implementeren, moet deze een sensitiviteit hebben van $\geq 95 \%$ en een specificiteit van $\geq 99 \%$.

\section{WAT IS NIEUW?}

- De onderzochte antigeensneltest [Panbio ${ }^{\mathrm{TM}}$ ] heeft in de eerstelijns spoedzorg een sensitiviteit van 65,7\% bij patiënten met matig-ernstige klachten [dit verbetert tot $80,7 \%$ indien de drempelwaarde voor een negatieve PCR-test wordt verlaagd van CT 45 naar CT $\geq 32$ ].

- De kans op een fout-negatieve uitslag van de antigeentest is $2-5 \%$.

- Bij patiënten die zich op de eerstelijns spoedzorg melden met corona-achtige klachten en een negatieve sneltest, is het aan te raden de uitslag te bevestigen met een PCR-test.

uur duurt voor het testresultaat bekend is. Antigeensneltests kunnen dan een uitkomst bieden als men grote groepen mensen wil screenen en snel wil starten met bron- en contactonderzoek in geval van een positieve testuitslag. Het is echter bekend dat antigeentests minder gevoelig zijn dan PCR omdat ze pas positief uitslaan wanneer de hoeveelheid virusdeeltjes (viral load) groot genoeg is.

Onze resultaten laten zien dat bij gebruik van Panbio $^{\mathrm{Tm}}$ als diagnostische test in een populatie die door de huisarts naar de coronaspoedpost was verwezen (en dus al COVID-19-achtige klachten had), 34,3\% van de diagnoses 'COVID-19' wordt gemist. We concluderen daarom dat deze antigeentest niet geschikt is als diagnostische test voor deze groep. Dat de patiënten met een fout-negatieve antigeentest een klachtenduur van mediaan 9 dagen hadden, wijst erop dat zij pas relatief laat in de geïnfecteerde fase last kregen van het verergerde klinische beeld van COVID-19. Na besmetting met SARS-CoV-2 neemt de viral load exponentieel toe, bereikt binnen enkele dagen een piek en neemt daarna gestaag af. De lage sensitiviteit die wij vonden, kan echter maar ten dele verklaard worden door het relatief late moment van testen. De antigeentest miste namelijk ook 11 PCR-positieve patiënten met een korte ziekteduur en met lage CT-waarden, wat correspondeert met een grotere viral load. Volgens de fabrikant heeft de Panbio ${ }^{\mathrm{rm}}$ antigeentest een sensi- 


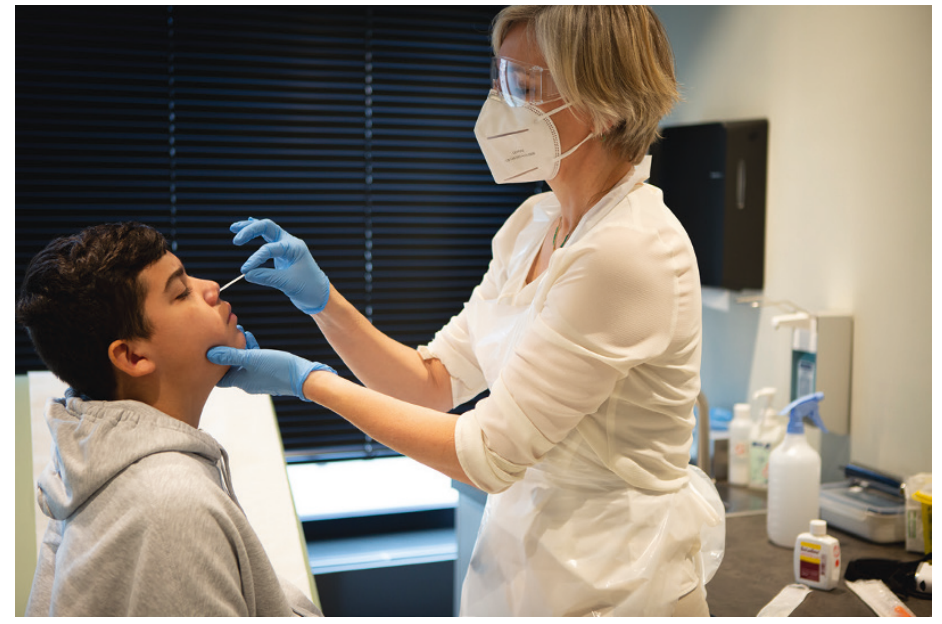

Bevestig een negatieve antigeensneltest bij patiënten met klachten altijd eerst met een PCR-test

Foto: Margot Scheerder

tiviteit van 93,3\%, die oploopt tot 98,2\% wanneer de drempelwaarde voor een negatieve PCR-uitslag verlaagd wordt tot CT $>33 .{ }^{10}$ De sensitiviteit van $65,7 \%$ die wij vonden, is in overeenstemming met recent validatieonderzoek in mild-symptomatische populaties, waarin de gerapporteerde sensitiviteit van de antigeentest varieerde van 57,6 tot $79,6 \%$. $^{3,6,11-14} \mathrm{Wij}$ vonden dat de antigeentest een sensitiviteit van $80,7 \%$ had ten opzichte van PCR met drempelwaarde CT $\geq 32$; daarmee voldeed de antigeentest niet aan het vooraf gestelde criterium voor implementatie van de antigeentest (sensitiviteit $\geq 95 \%$ ). Een Nederlands onderzoek met de Panbio ${ }^{\mathrm{Tm}}$ antigeentest vond met drempelwaarde CT $\geq 32$ een sensitiviteit van $95,2 \%$ bij mild-symptomatische mensen in de algemene bevolking. ${ }^{3}$ Spaanse onderzoekers beschreven, evenals wij, een hogere sensitiviteit wanneer zij alleen patiënten includeerden met een klachtenduur $<7$ dagen. ${ }^{13}$ In hun onderzoek verbeterde de sensitiviteit van de antigeentest daardoor tot $86,5 \%$, in ons onderzoek tot $70,3 \%$.

Het moment in de pandemie waarop de antigeentest wordt afgenomen, heeft grote invloed op de voorspellende waarde. Een test afgenomen tijdens een hoge prevalentie van besmettingen, zoals tijdens de piek van een besmettingsgolf, heeft namelijk een hogere positief voorspellende waarde dan een test in een periode van weinig besmettingen. Bij een lage prevalentie wordt de negatief voorspellende waarde juist hoger. ${ }^{15}$ Zouden we de resultaten van ons onderzoek interpreteren als voorspellende waarden voor een andere groep patiënten of een andere populatie, dan zou er selectiebias (spectrumbias) kunnen ontstaan. Dit illustreert het belang van de vele validatieonderzoeken in Nederland met antigeentests in steeds verschillende populaties.

Uit ons onderzoek blijkt de kans dat iemand met een negatieve antigeentest toch PCR-positief is voor SARS-CoV-2, en dus mogelijk besmettelijk is, $2-5 \%$. Het belangrijkste voordeel van de antigeentest is dat een positieve sneltestuitslag tijdwinst oplevert in het kader van infectiepreventie. Aan de andere kant kan een negatieve testuitslag leiden tot een zekere schijnveiligheid. Bij het gebruik van deze antigeentests moet daarom te allen tijde worden benadrukt dat een negatieve uitslag geen vrijbrief is voor het negeren van de basismaatregelen (anderhalve meter afstand houden en bij klachten thuisblijven).

\section{CONCLUSIE}

Het lijkt er vooralsnog op dat het onverstandig is antigeensneltests in te zetten als enige test bij het screenen van symptomatische patiënten in de eerstelijns spoedzorg. Het blijft de individuele keuze van de huisarts hoe hierop het beleid in de praktijk aan te passen. In sommige praktijken is het misschien mogelijk om patiënten met COVID-19-achtige klachten en een negatieve antigeentest bijvoorbeeld te zien in een aparte spreekkamer met de standaard beschermingsmaatregelen (afstand, medisch mondmasker, extra hygiëne), of aan het einde van het spreekuur. Dit is in lijn met de aanbevelingen in het NHG-dossier Coronavirus om een negatieve antigeensneltest bij kwetsbare patiënten altijd te bevestigen met een PCR-test. Pas als uit toekomstig onderzoek zou blijken dat de negatief voorspellende waarde van de antigeentest hoger wordt onder bepaalde voorwaarden (bijvoorbeeld duur of aard van de klachten), kan de positie van de antigeentest in de eerstelijnszorg heroverwogen worden.

\section{LITERATUUR}

1. Status validatie SARS-CoV-2 antigeen sneltesten: Status per 4 januari 2021. Bilthoven: RIVM, Centrum Infectieziektebestrijding, 2021. https://lci.rivm.nl/antigeensneltesten.

2. Bonten MJ. Covid-19: hoe betrouwbaar zijn sneltesten? Ned Tijdschr Geneeskd 2020;164:C4678.

3. Gremmels H, Winkel BM, Schuurman R, Rosingh A, Rigter NA, Rodriguez O, et al. Real-life validation of the Panbio ${ }^{\text {Tw }}$ COVID-19 antigen rapid test (Abbott) in community-dwelling subjects with symptoms of potential SARS-CoV-2 infection. EClinicalMedicine 2020:100677.

De volledige literatuurlijst staat bij dit artikel op www.henw.org.

Smits F, Torensma B, Groenwold RH, Leversteijn-Van Hall MA, Van Burgel ND, Jansen R, Essers H, Numans ME, Rosendaal FR, Mook-Kanamori DO. De SARS-CoV-2-antigeentest is niet accuraat genoeg. Huisarts Wet 2021;64[8]:42-4. D0l:10.1007/s12445-021-1159-2. Leids Universitair Medisch Centrum, afdeling Klinische epidemiologie, Leiden: F. Smits, medisch student/onderzoeker en junior triagist; B. Torensma, klinisch epidemioloog; prof. dr. R.H.H. Groenwold, hoogleraar klinische epidemiologie; prof. dr. F.R. Rosendaal, hoogleraar klinische epidemiologie; dr. D.O. Mook-Kanamori, huisarts-onderzoeker: d.o.mook@lumc.nl. Alrijne Ziekenhuis, afdeling Medische microbiologie, Leiderdorp: M.A. Leversteijn-Van Hall, medisch microbioloog. Haga Ziekenhuis, afdeling Medische microbiologie, Den Haag: dr. N.D. van Burgel, medisch microbioloog. HADOKS Acute Zorg, Den Haag: dr. R. Jansen, voorzitter Raad van Bestuur. Huisartsenposten De LIMES, Leiderdorp: H. Essers, kaderhuisarts spoedzorg. Leids Universitair Medisch Centrum, Campus Den Haag, afdeling Public health en eerstelijnsgeneeskunde: prof. dr. M.E. Numans, hoogleraar huisartsgeneeskunde. Mogelijke belangenverstrengeling: dr. Leversteijn-van Hall is tevens werkzaam als medisch manager bij Eurofins Clinical Diagnostics. Dit onderzoek werd mede mogelijk gemaakt door een COVID-19-subsidie van ZonMw, nr. 10430022010003 